Pamiętnik Literacki 2021, 2, s. 171-179

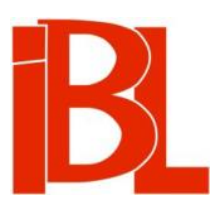

\title{
Polonistyka światowa i jej perspektywy
}

Filip Mazurkiewicz 


\section{POLONISTYKA ŚWIATOWA I JEJ PERSPEKTYWY}

Teraz, kiedy zostaliśmy sami, kiedy polonistyka formalnie już nie istnieje, kiedy rozpłynęła się w literaturoznawstwie, humanistyce i w czym tam jeszcze, my, poloniści, ostatecznie wyzwoleni $z$ instytucjonalnych ram dyscypliny, możemy przyjrzeć się polonistyce i sobie samym na nowo. Wrzuceni w nowe regulacje, podziały i statuty, które mniej lub bardziej podważyły i przekształciły porządek uniwersytetu, czyli porządek wiedzy i przyzwyczajenia, musimy rozpatrzyć się w tym nowym położeniu, gdzie słowo „położenie”, oznaczające i 'miejsce', i 'ukształtowanie' („położenie ciała”, „położenie geograficzne”, „dobre/złe/trudne położenie”), potraktować trzeba w całej jego złożoności semantycznej. Na to pokątne $z$ instytucjonalnego punktu widzenia spotkanie ${ }^{1}$ przynosimy naszą kontrabandę - choć $z$ jednej strony wciąż polonistyczną, to już po nowemu literaturoznawczą. Chodzi z grubsza o to, że dotąd uprawialiśmy literaturoznawstwo jako poloniści, teraz będziemy uprawiać polonistyke jako literaturoznawcy i nie jest to tylko kosmetyczne przesunięcie akcentów lub gra słów, lecz doniosła zmiana perspektywy. Decyzja ustawodawcy polonistyka właśnie rozpływa się w dyscyplinie bardziej światowej, mniej geograficznej, podlega uświatowieniu. Przynajmniej takie wytyczono przed nią cele. Właśnie te dwa pojęcia: światowość i perspektywę, chciałbym dziś w kontekście polonistyki przemyśleć. Choćby po to, byśmy się mogli zorientować, co pokażemy urzędnikom i naukometrom ustawieni w zgrabne dwuszeregi na placu apelowym najbliższej ewaluacji.

\section{Światowość}

Pytanie, czy polonistyka jest światowa, stanowi pod pewnymi względami wariant pytania, czy polska literatura jest światowa, ponieważ tam, gdzie mowa o polskiej literaturze, prędzej czy później potrzebny okazuje się polonista - tak to działa nie tylko $\mathrm{w}$ teorii, ale i w praktyce. A zatem światowa ważność polonistyki stanowi prostą konsekwencję miejsca polskiej literatury w świecie. Moje skromne doświad-

1 Tekst ten pisany był z myślą o Zjeździe Polonistów, który miał się odbyć na Uniwersytecie Warszawskim 26-28 III 2020 pod hasłem Polonistyka „tu i teraz”. Krajobraz po ustawie 2.0. Panelowi Polonistyka - perspektywa lokalności i globalizacji (języka, literatury, kultury) przyświecały następujące hasła wywoławcze: 1. językowe konsekwencje global nation; 2. polonistyka w kontekstach międzynarodowych; waga perspektywy Europy Środkowo-Wschodniej; 3. jezzyk polski a kultury; 4. szanse literatury polskiej na globalnym rynku (np. „Azja patrzy na polonistykę). W niniejszym tekście próbowałem w miarę możności stworzyć podstawę teoretyczną do dalszej dyskusji. Zjazd odwołano $z$ powodu pandemii. 
czenia płynace $\mathrm{z}$ pobytu $\mathrm{w}$ kilku krajach $\mathrm{w}$ ramach wymiany naukowej (w tym z półrocznego stażu naukowego odbytego na uniwersytecie w Hongkongu) podpowiadają, że miejsce to jest całkiem przyzwoite. Spotkałem Australijczyka, który mówił o swoim ulubionym poecie Czesławie Miłoszu, nim jeszcze się dowiedział, że rozmawia $z$ historykiem literatury polskiej; spotkałem subtelnych znawców Stanisława Lema $z$ Nowego Jorku, miłośników Brunona Schulza z Tajwanu, licznych czytelników Olgi Tokarczuk z Chin i Hongkongu, którzy narzekali na kiepskie przekłady jej powieści na chiński, francuskiego teatrologa, który przekonywał mnie, że Witold Gombrowicz pisał lepsze dramaty od Jeana Geneta (i nie przekonał), oraz sinolożkę z Bolonii, która znacznie lepiej ode mnie znała życie i dorobek Michała Boyma. O takich spotkaniach można by długo opowiadać, ale wniosek zawsze pozostaje ten sam: polska literatura jest, moim zdaniem, dobrze (lub raczej: odpowiednio) obecna w świadomości czytelników na świecie. Zajmuje należne jej miejsce literatury średniej wielkości - daleko jej zarówno do wielkich literatur imperialnych, jak i do literatur małych krajów i jezzków.

W związku z tym za ciekawsze i bardziej pożyteczne uważam przemyślenie sensu i istoty owej światowości i jej konsekwencji dla możliwej światowości polonistyki, czyli takiego literaturoznawstwa, którego przedmiotem zainteresowania jest i pozostanie literatura polska.

Światowość to, zdaniem Martina Heideggera, jeden z dwóch głównych komponentów dzieła sztuki. Teza filozofa, załóżmy, że prawdziwa, brzmi z grubsza tak: źródło dzieła sztuki - w zasadzie każdego, a zatem literackiego również - stanowi zasadniczy spór, który toczy się pomiędzy ziemią a światem. Zdaniem myśliciela, ziemia wspiera i wystawia świat, świat zaś przykrywa ziemię, dominuje nad nią. $Z$ tego sporu wyłania się dzieło sztuki. Światowość byłaby więc dla Heideggera przeciwieństwem ziemi. Jednakże bez ziemi, bez styczności z ziemią, bez zrozumienia własnej ziemi (tzn. tej konkretnej, którą zamieszkujemy) nie ma dzieła sztuki. Tu więc być może kryje się najistotniejsza kwestia: bez radykalnego przemyślenia stosunku do ziemi nie rozwiążemy sprawy światowości polskiej literatury. W Heideggerowskich metaforach brzmi to tak:

Dziejowy człowiek na ziemi i w niej gruntuje swoje zamieszkiwanie w świecie. Wystawiając świat, dzieło ustawia ziemię. [...] Dzieło wsuwa samą ziemię w Otwarte świata i w nim ją utrzymuje. D zi eło pozwala ziemi być ziemią .

Dlaczego? Ponieważ w dziele dochodzi do głosu pewna fizyczność, zachowująca materialność materiału, $\mathrm{z}$ którego dzieło zostało wytworzone:

wystawiając świat, [dzieło] nie pozwala materiałowi zniknać, lecz przede wszystkim pozwala mu wystąpić [...] w Otwarte świata dzieła: skała zaczyna dźwigać i spoczywać i w ten sposób dopiero staje się skałą; metale zaczynają błyszczeć i lśnić, barwy świecić, dźwięk brzmieć, słowo powiadać [artykułować, mówić - M. H.]. Wszystko to występuje, kiedy dzieło ustępuje przed masywnością i ciężkością kamienia, trwałością i giętkością drewna, twardością i połyskiem brązu, świetlistością i ciemnością farby, brzmieniem dźwięku i nazywającą siłą słowa ${ }^{3}$.

2 M. He i de g g e r, Źródło dzieła sztuki. Przeł. J. Mi ze r a. W: Drogi Lasu. Warszawa 1997, s. 30-31.

3 Heidegger, op. cit., s. 30. 
Rzeczywiście, w literaturze polskiej ten spór jest bardzo zasadniczy: ziemia, konkretna ziemia i świat, który ją przykrywa, lecz spod którego ona jakby wystaje, wzywa, odrywa od tego świata. Ziemia, która przychwyca i przykuwa pisarzy tutejszych, czasem dla niepoznaki znika im z oczu, ale jest niezbywalnym parametrem pisania. Soplicowo Mickiewicza, Drohobycz Schulza, dolina Issy Miłosza czy Zakopane późnego Gombrowicza. Ziemia, która pociąga pisarzy emigracyjnych, przenosi ich w inne miejsce („każdy kwiatek powie wiersze Zosi, / Każda jej gwiazdka piosenkę zanuci” ${ }^{4}$, zdradza. Zmierzam do tego, że światowość polskiej literatury możliwa jest jedynie poprzez jej ziemskość, czyli tutejszość, dopiero później uświatowioną. Heidegger pisze, że gdy dzieło sztuki unaocznia spór ziemi ze światem, wtedy objawia też jakąś swoją prawdę. To jest zapewne prawda o nas, albo - prawda nasza, dochodzaca do głosu w naszym języku, na naszej ziemi, na świecie, który zamieszkujemy. Tylko my potrafimy dobrze usłyszeć ten głos, a potem opowiedzieć o tym zdarzeniu innym - także w obcych językach. Tylko dopóki trzymamy rękę na pulsie tego splotu, dopóki słuchamy języka, w jakim się on wyraża, dopóki zachowujemy fizyczny kontakt z tą fizycznością, wciąż przykrywana przez świat, dopóty w ogóle możemy mieć komuś coś gdzieś do powiedzenia.

Rzecz zatem nie w tym, czy polonistyka będzie lokalna, czy globalna - jakby istniał tu jakiś wybór. Rzecz w tym, że $z$ samej istoty materiału, w którym polonista pracuje, oraz $\mathrm{z}$ istoty słowa, które jako cytat wsacza się w jego własne słowo, polonistyka jest jednocześnie globalna i lokalna. W tym sensie, rozpuszczona w różnojęzycznym i multiliteraturowym literaturoznawstwie, stanowi element swoisty i osobny. Niekoniecznie uprzywilejowany, co chciałbym zaakcentować, ale osobny w tym sensie, że np. polski anglista musi swe miejsce i swój głos przemyśleć inaczej niż polonista; ich miejsca w lokalności i globalności są inne, mimo że łączy ich dziś jedna dyscyplina badawcza. W tym zestawieniu angliście tylko pozornie łatwiej własne miejsce określić - to jednak osobna sprawa ${ }^{5}$.

Opisując lokalność i globalność za pomocą sporu ziemi i świata, czynię to dlatego, że pragnę zaznaczyć, iż polonistyka jest zawsze zawieszona w tej podwójności, jest i lokalna, i globalna. Wynika to $z$ jej istotowego charakteru, a nie $z$ czyjegoś wyboru. Inaczej jeszcze mówiąc, będąc polonistą, i to gdziekolwiek na świecie - nieważne, gdzie - nie sposób zajmować się światem $z$ pominięciem ziemi ani ziemią z pominięciem świata. Polska literatura, czyli nasz materiał, zawsze przywoła nas z powrotem, gdy spróbujemy być zanadto światowi, a za mało ziemscy. Podobnie gdy zwycięży ziemia - stracimy wtedy kontakt ze światem i nikt ani nie zrozumie, ani nawet nie usłyszy naszego głosu. Polonistyka ze swej istoty nie może być ani ksenofobiczna, ani kosmopolityczna, bo w każdym $z$ tych skrajnych wariantów porzuca materiał stanowiący przedmiot jej zainteresowania, czyli nie jest już nauką o dziełach sztuki, lecz publicystyką uniwersytecką. Czasem nawet wybitną, lecz oddzieloną od swego przedmiotu, który w związku z tym przestaje już umocowywać jej istnienie.

Sprowadzenie sporu ziemi ze światem do tych dwóch prostych kategorii (kse-

4 J. Słow a c ki, [W pamiętniku Zofii Bobrówny]. W: Wiersze drobne z lat 1843-1849. Oprac. J. Kle ine r, J. Kuźni a r. Wrocław 1960. Dzieła wszystkie. T. 12, cz. 1, s. 183.

$5 \quad$ Przemyśleć warto pojawiającą się tu kwestię sytuacji polonisty, dla którego język polski nie jest natywny. Analogia z polskim anglistą sama się narzuca. 
nofobia/kosmopolityzm) nie zmierza do wulgaryzacji rozpatrywanego sporu. Przeciwnie: zmierza do skomplikowania owych kategorii w taki sposób, aby oddzielić polonistykę od polityczności i tym samym zamknąc drogę do rozgrywania sporu w kategoriach politycznych. Polonistyka, która opuszcza ziemię, aby stać się kosmopolityczna, lub która opuszcza świat, aby osunąc się w ksenofobię, nikogo nie zainteresuje. To bowiem, co ma szansę zaciekawić, to osobność wkraczająca w powszechność i zachowująca jednocześnie źródłowy spór, z którego sama wynika, którym sama jest. Polityczność nie może i nie powinna być tu żadnym liczącym się parametrem, ponieważ w sporze owym nie chodzi o anihilację przeciwnika. Heidegger pisał:

Przeciwieństwo świata i ziemi jest sporem. Nazbyt łatwo [...] wypaczamy istotę sporu, nie odróżniając jej od waśni i zwady; dlatego znamy spór tylko jako przeszkodę i rozkład. Wszelako w istotowym sporze spierający się wspierają się w samopotwierdzeniu swojej istoty. [...] Ziemia nie może obejść się bez Otwartego świata [...]. Świat zaś nie może wymknąć się ziemi [...] ${ }^{6}$.

Polonistyka udająca obywatelkę świata, w którym polskość nie jest parametrem, albo polonistyka udająca polskość, która realizuje się jako tożsamość, a nie jako różnica, to dwa typy nieczytelnej amorficzności skrojone na użytek mądrości etapu politycznego czy mody intelektualnej, a nie na miarę dzieła sztuki. Nie chodzi mi więc o łagodzenie przeciwieństw, o zajmowanie umiarkowanej postawy pomiędzy biegunami opozycji, lecz o ukazanie, że jedynie trwanie w sporze, nieredukowanie go umożliwia uprawianie polonistyki jako nauki lokalnej o wymiarze światowym, ponieważ tylko wtedy możemy wypowiedzieć ów istotowy spór, charakterystyczny dla naszej ziemi i naszego świata.

Przechodze teraz do kwestii perspektywy. Jakie są perspektywy dla takiej polonistyki, dla takiego literaturoznawstwa? I najważniejsze: co w tym przypadku oznacza perspektywa jako taka?

\section{Perspektywy}

Perspektywa, pisze Rafał Kuczyński w eseju porównującym myśl Erwina Panofsky’ego i Pawła Florenskiego na ten temat, jest „swoistym skrótem myślowym czy też metaforą, w której w jedno łączą się, $\mathrm{z}$ jednej strony, postrzeganie rzeczywistości, $z$ drugiej - jej ocena, a więc percepcja i sąd" ${ }^{7}$. A do tego jeszcze jakieś widzenie przyszłości - i to trzecie znaczenie wcale nie unieważnia pierwszego. „Perspektywa” - pisał Michał Paweł Markowski - ,jest aprioryczną konstrukcją rozumu porządkująca przestrzeń widzialną" 8 . Teoretycy sztuki, rozważając symboliczne znaczenie perspektywy rozumianej jako wyraz najogólniejszych ram postrzegania świata, wyznaczali dwa jej typy - perspektywę linearną i perspektywę odwróconą.

[Panofsky z jednej strony, Florenski - z drugiej] przyjmują w swych analizach zbliżone kategorie, wyróżniając dwa rodzaje przestrzeni: psychofizjologiczną, a więc przestrzeń bezpośredniego doświad-

$6 \quad$ Heidegger, op. cit., s. 33.

7 R. Ku czyńs ki, Perspektywa wyboru. Erwin Panofsky, Pawet Florenski. „Kronos” 2019, nr 3, s. 138.

8 M. P. Mar k ow s ki, Pragnienie obecności. Filozofie reprezentacji od Platona do Kartezjusza. Gdańsk 1999, s. 138. 
czenia zmysłowego, [...] oraz abstrakcyjną przestrzeń matematyczną. Dwóm rodzajom przestrzeni odpowiada [...] odmienny i ewoluujący w czasie sposób rozumienia rzeczywistości, co z kolei wyrażone jest przy pomocy różnych technik obrazowania przestrzeni. Przestrzeń abstrakcyjną zarówno Panofsky, jak i Florenski wiążą z jej nieskończonym i niezróżnicowanym wyobrażeniem symbolizowanym przez perspektywę linearną; przestrzeń psycho-fizjologiczną - którą obaj określali mianem „naturalnej” - pierwszy kojarzy z tak zwaną perspektywą krzywoliniowa, drugi z perspektywą odwróconą ${ }^{9}$.

Ostatecznie perspektywa linearna stanowi odzwierciedlenie i matrycę oświeceniowego lub, szerzej, nowoczesnego sposobu oglądu świata i podejścia do rzeczywistości. W tym rozumieniu perspektywa taka jest modelem zachodniego rozumu wraz ze wszelkimi jego dalszymi konsekwencjami, które znamy - i mam tu na myśli złożony, ambiwalentny sens zachodniej nowoczesności:

Zrodzony w sferze przedstawień artystycznych matematyczny model nieskończoności poprzedza historycznie kantowskie, pojęciowe ujęcie przestrzeni. Dlatego też dla Panofsky'ego perspektywa, a wraz z nią sztuka w ogóle, stanowi awangardę kształtowania się nie tylko nowożytnej nauki, ale i nowożytnego, racjonalnego światopoglądu i równie racjonalnego współczesnego podmiotu ${ }^{10}$.

Drugi rodzaj perspektywy natomiast „[...] Florenski dostrzega w ikonie prawosławnej, wyrosłej z ikonografii bizantyjskiego średniowiecza, która z kolei zakorzeniona była [...] w antycznych technikach obrazowania" ${ }^{11}$. Sztuka oparta na zasadzie odwrotnej wobec perspektywy linearnej to, zdaniem Florenskiego, sztuka czysta, ta zaś -

zapośredniczona przez twórcze natchnienie artysty, jest wyrazem głębokiego, religijnego obrazu świata. [...] Nie jest to wszak Prawda wyłącznie chrześcijańska, lecz znacznie szerzej, Prawda religijna i religijny obiektywizm. [...]

Florenski wyraźnie wartościuje owe dwa obrazy świata. Perspektywa linearna jest [...] źródłem przedstawień ograniczonych, ale i ograniczających ludzkie poznanie rzeczywistości. [...]

Inaczej działa sztuka czysta. Jej celem nie jest tworzenie iluzji rzeczywistości, lecz odzwierciedlenie prawdy o niej. Dlatego też dzieło sztuki czystej nie rości pretensji do bycia czymś, czym nie jest, to znaczy wycinkiem realnego świata, ale otwarcie przyznaje się do bycia jego symbolicznym zapośredniczeniem $^{12}$.

Model ten, jak nietrudno się domyślić, odsyła nas do zasadniczych dualizmów wiedzy i wiary, rozumu i serca, materializmu i idealizmu. Odsyła nas także do tego, co wschodnie, i w ten sposób domyka symboliczny i intelektualny podział świata na Zachód i Wschód, Okcydent i Orient. Koło się zamyka. Równie łatwo dojrzeć, że oba modele maja charakter imperialny, opozycja ma zaś charakter właśnie domykający. Przynajmniej o tyle, o ile rozumiemy już, że perspektywa jest zarówno pewnym konkretnym modelem świata, jak i fatum historycznym, ciążącym nad miejscem, które $z$ kolei przypomina nam o ziemi.

W tych rozróżnieniach perspektywy, używanych tu jako synekdocha szeroko pojętych formacji kulturowych, chodzi mi przede wszystkim o miejsce mowy i teoretyczna (dokładniej: teoretycznoliteracka) cudzożywność. Nie sprowadza się ona tylko do prostych wyborów, lecz określa świadomość, wysterowuje ją, właśnie:

Kuczyńs ki, op. cit., s. 141.

Ibidem, s. 143.

Ibidem, s. 141.

Ibidem, s. 144-145. 
perspektywizuje. To, co na pozór podlega wolności wyboru, u spodu okazuje się efektem oddziaływania hegemonicznego. Inaczej rzecz ujmując: to nie my mówimy, lecz język mówi nami w ramach określonego reżimu prawdy.

Nasza ziemia jednak, położona pomiędzy Okcydentem a Orientem, wychyla się ku obu perspektywom; wolno rzec także, iż kiedy stoimy na naszej ziemi, świat przedstawiać nam się może w obu perspektywach, wybór zaś - mniej lub bardziej od nas samych zależny - podlega też ciśnieniom historycznym, politycznym i innym (np. ekonomicznym), hegemonicznym bądź imperialnym. Sądzę, że oba te czynniki trzeba brać pod uwagę, zastanawiając się nad światowością i perspektywami polonistyki (lub dla polonistyki). Rozpięcie między lokalnością a globalnością może być dopiero dalszym krokiem w rozumowaniu i z zarysowanego dotąd punktu widzenia wydaje się alternatywą pozorna. Tak jak nie ma lokalności poza globalnością, tak samo nie ma prostego wyboru pomiędzy zachodnią i wschodnią perspektywa, w jakiej wolno byłoby postrzegać dziedzinę i przedmiot jej zainteresowania. Bliski mi przykład badań nad męskością ukazał jasno, że zachodnie kategorie wypracowane w studiach genderowych nie opisuja polskiej specyfiki problemu, i to już od poziomu gramatycznego, leksykalnego, pojęciowego, aż po najwyższy: poziom formacji dyskursywnych. Na podobne kłopoty natrafiły m.in. analizy zorientowane postkolonialnie i postzależnościowo. Zamiast mnożyć przykłady, warto przypomnieć zdania Irzykowskiego ze słynnego tekstu o plagiatowym charakterze przełomów literackich w Polsce:

Tzw. nić tradycji narodowej to nie żadna piła patriotyczna, to nie wywąchiwanie jakichś postulatów mistycznych (tzw. docieranie do głębin duszy narodowej), lecz po prostu ciagłość własnej myśli, rozrastającej się. Gdy się ta myśl raz przerwie, najczęściej nie warto już odnawiać jej, trzeba skakać i gonić, bo świat już poszedł dalej.

Co do takich różnych wątków, które by w literaturze naszej mogły się stać tradycją, to jedno z dwojga: albo krytyka nie spełniała swego zadania i zaniedbywała te wątki reklamować, albo spełniała je aż nadto dobrze, to znaczy zaniedbywała rodzime wątki rozmyślnie, znajdując za granicą wątki o wiele cenniejsze ${ }^{13}$.

Na przytoczone zdania spojrzeć można zarówno z punktu widzenia dzieła jako sporu ziemi ze światem, jak i w kontekście problemów z perspektywa, co w tej części rozważań jest bardziej istotne. Otóż Irzykowski, pisząc o porzucaniu tematów, o przeskokach i o ciagłych koniecznościach doganiania (świata, trendów, mód itd.), ale i pisząc raz o epigońskiej, innym razem o prometejskiej roli krytyki, pisze właśnie o pewnej swoistości, która nie da się sprowadzić do żadnej z omówionych perspektyw. Raczej - tak przynajmniej chciałbym czytać to, co w tekście Irzykowskiego niewypowiedziane wprost, lecz obecne - wyłania się tu niezbędność ustanowienia własnej perspektywy, która uwzględniałaby światowo-lokalną szczególność.

Polonistyka przez ostatnie kilkadziesiąt lat przeszła przez fascynacje płynące ze Wschodu, potem z Zachodu, dziś przechodzi fazę amerykańską. Nadążając za światowymi modami, przyjmuje zmienne perspektywy, które ukonstytuowały się źródłowo do opisu innych zjawisk literackich czy kulturowych. Mówiąc to samo w języku, jaki staram się tu zaproponować, literacki materiał - dzieła - wyrasta

13 K. I r zy k ow s ki, Plagiatowy charakter przełomów literackich $w$ Polsce. W: Stoń wśród porcelany. Lżejszy kaliber. Kraków 1976, s. 62-63. 
tam ze sporu innego świata $z$ inną ziemią i dlatego nadążając za światową humanistyką, nigdy za nią nie możemy nadążyć, gdyż jest ona jak horyzont - oddala się w miarę zbliżania się do niej. W tej pogoni ziemia ucieka nam spod nóg, ale jednocześnie nas zatrzymuje. Powstaje rozziew, który nazywamy własnym opóźnieniem (opóźnieniem wobec Zachodu, wobec najlepszych itd.). To poczucie opóźnienia zostało zdemokratyzowane i zglobalizowane i dziś ten, kto nie wie, co ostatnio pisza najczęściej cytowani uczeni amerykańscy, stoi na przeszkodzie nie tylko sobie samemu (samej), ale i szkodzi placówce naukowej, do której „liczby n” przynależy. Krąg nieszczęścia się zamyka, ponieważ tamtym wzrasta liczba cytowań, podwyższa się pozycja ich uniwersytetów w rankingach, a nasze uczelnie pozostają na dawnym niskim poziomie lub spadają. Opóźnienie jeszcze się więc pogłębia - i tak w nieskończoność. Dyscyplinowe połączenie polonistyki z globalnym literaturoznawstwem postawiło tu tylko kropkę nad „i”.

I nie jest to - powtórzę - wyłącznie nasz problem. Został zglobalizowany w interesie najmocniejszych graczy na planetarnym rynku nauki. Przykładowo, w Chinach dyskutuje się kwestie nieprzystawalności kategorii zachodniego myślenia do chińskiego genius loci i wypływającej z tego konieczności wytworzenia kategorii odmiennych oraz - cokolwiek miałoby to oznaczać - własnych. W związku z tym, na koniec, kilka uwag na temat perspektyw, które otwieraja się przed światowa humanistyką w wyniku protestów w Hongkongu.

\section{Semiotyka protestu}

Każde miasto posiada swój mit założycielski. Mit Hongkongu, o którym chciałbym na zakończenie powiedzieć kilka słów, jest to mit brytyjskiego kolonializmu, ufundowany na założycielskim geście stworzenia właściwej mapy. Wszystko to do złudzenia przypomina gest stworzenia świata:

W styczniu 1841 HMS „Sulphur”, pod komendą kapitana Edwarda Belchera, badał wody okalające wyspę Hongkong. Był to ostatni etap badawczej podróży dookoła świata, którą „Sulphur” odbywał w latach 1836-1842. Powstała w efekcie Hong Kong Nautical Chart [Mapa żeglugowa Hongkongu] była pierwszą naukową mapą wyspy Hongkong, a jednocześnie pierwszą mapą Hongkongu poddanego Wielkiej Brytanii. Nakreślona wtedy mapa była bardzo ceniona za rygorystyczna precyzję pomiarów i zaświadczała o wysokim poziomie kartografów Royal Navy. [...] W ten sposób Hongkong narodził się na HMS „Sulphur” pływającym pod kapitanem Belcherem. Dla upamiętnienia tych wypadków północno-zachodnią część wód wokół wyspy nazwano Zatoką Belchera, a zamykający ją przesmyk - Kanałem Sulphur ${ }^{14}$.

24 I tego samego 1841 roku, w związku z przeciagającymi się rozmowami pokojowymi o zakończeniu pierwszej wojny opiumowej, podjęto decyzję o okupacji wyspy. Jest to zdarzenie w historii tego miejsca zasadnicze i kreacyjne:

Gdyby Brytyjczycy nie zdecydowali się na okupację wyspy i utworzenie kolonii, wtedy Hongkong, jaki dziś znamy, nie istniałby. [...] podkreślenia wymaga fakt, że Hongkong został wymyślony i jest to jeden $\mathrm{z}$ tych cudownych wymysłów w historii ludzkości. Hongkong bowiem był tworem fikcyjnym [work of fiction] już od samego początku ${ }^{15}$. 
Być może jest nim też do dziś, mimo że po drodze wiele się stało i zmieniło. Hongkong w każdym razie do teraz pozostaje miejscem przesyłu i przejścia, progiem lub bramą pomiędzy Chinami a resztą świata ${ }^{16}$. Miasto, którego ludność stanowi mieszaninę różnych fal emigrantów z potomkami miejscowych rybaków i rolników ${ }^{17}$, w 2019 roku stało się areną spektakularnych protestów. Ich stawką polityczną były demokratyczne wybory, niezależność sądownictwa i kwestia ekstradycji. Protesty miały charakter masowy ${ }^{18}$, a ich skala zapierała dech, nie to jednak sprawia wrażenie najistotniejszego w perspektywie naszych rozważań. Istotna okazuje się przestrzeń demonstracji, która wydaje się bardziej wirtualna niż realna. Ciekawa jest też wizualna i tekstowa sfera jego identyfikacji. W efekcie widzimy proces zanikania tradycyjnego podziału na tłum i jego przywódców. Zwirtualizowanie protestu połączone $z$ nowoczesnymi technologiami identyfikacji twarzy oraz pozycjonowania urządzeń mobilnych spowodowały, że nikt nie należy już do anonimowego tłumu, który znika w bocznych ulicach, ani nikt nie jest przywódcą, którego można by łatwo zaaresztować, przekupić, zastraszyć lub wygnać. Tym samym falowanie protestu, jego erupcje i stłumienia stają się tyleż wyrazem woli społecznej, co wypadkową działania anonimowych algorytmów poruszających tryby mediów społecznościowych. Do tego dochodzi bezkresna przestrzeń identyfikacji wizualnej rozgrywającej się w tysiącach ulotek, plakatów, wlepek i graffiti, które pokrywają oficjalny tekst miasta niezliczonymi tekstami wywrotowymi. Teksty i obrazy usunięte przez służby miejskie błyskawicznie zastępowane są przez nowe. Tekst rozchwiewa się i przyrasta - a mówię tu tylko o przestrzeni analogowej: muru, papieru, farby. Poza tym mamy wirtualne grupy, wydarzenia, streamy, blogi, vlogi itd. - ocean tekstów i obrazów stanowiący wyraz determinacji i kreatywności o trudnych do wyobrażenia skali i rozmachu. W nowym świetle jawi się tu podstawowy problem wieloautorskiego rozproszenia i problemowo-tematycznej konsolidacji, czyli autora, granic tekstu, ram modalnych, adresata i przestrzeni wypowiedzi.

Czas na wyjaśnienie, po co o tym piszę. Otóż sądzę, że protest w Hongkongu stanowi bardzo szczególne wyzwanie dla tamtejszych humanistów. Spoczywa na nich bowiem nie tylko niełatwe zadanie gromadzenia, katalogowania i systematyzowania kolosalnego materiału, który przyrasta z każdym dniem i godziną. Jeszcze trudniejsze i ciekawsze wydaje się sprostanie potężnemu zapotrzebowaniu społecznemu na zupełnie nową opowieść o miejscu, opowieść założycielską, historyczną i zarazem ponowoczesna, demokratyczną, antyhegemoniczną, antyimperialną, niewykluczająca i (tak, tak) ekologiczna. Przy tym jednak perswazyjną i silną, antagonizującą i różnicującą. Społeczności potrzebna jest nowa opowieść, jaka sprostałaby historycznemu przebudzeniu, przez które owa społeczność przechodzi. Opowieść o brytyjskim statku, o jego kapitanie i o mapie imperialnej straciła przydatność, nowa zaś stanowi nie lada trudność. Jak bowiem pogodzić przeciwieństwo wyraźnie widoczne między współczesnymi językami humanistyki a potrzebą mocnej fabuły, która byłaby właśnie mocna, a zarazem wyrosłaby $\mathrm{z}$ antyhegemonicznych, inkluzywnych i demokratycznych uwarunkowań słabych 
dyskursów? Jest jasne, że języki te, promieniujące w równym stopniu na nas, jak i na humanistów w Hongkongu, z jednej strony, nie dają im narzędzi do napisania owej historii, $z$ drugiej wszakże, nie mogą i nie powinny być pominięte. Mówiąc inaczej: jak sprostać zapotrzebowaniu na prawdę w świecie postprawdy?

Znów pojawiają się więc moje dwa problemy: źródłowy spór ziemi ze światem, którego lokalny charakter nie da się wypowiedzieć w dostępnych humanistyce światowej światowych językach, oraz kwestia przyjęcia (właściwej) perspektywy, która wychodziłaby poza dostępne hegemoniczne perspektywizacje.

Wszelkie podobieństwa między Polską a Hongkongiem nie są przypadkowe, wskazanie ich było zamierzone, możliwe jednak, że pozostają tylko wymysłem i zmyśleniem piszącego te słowa, który wysnuł je na temat wymyślonego miasta, powróciwszy zeń do Polski - czyli nigdzie.

\section{Abstract \\ FILIP MAZURKIEWICZ University of Silesia, Katowice ORCID: 0000-0003-0702-4147 \\ GLOBAL POLISH STUDIES AND ITS PERSPECTIVES}

A recurrent problem in academic discussions is whether Polish studies are sufficiently global. It often appears that they are not. That they lack globality. The next question posed concerns their perspectives. The paper is an attempt to give an answer to a more detailed issue, namely which global perspectives Polish studies will face in the future, considering the fact that the discipline is, on the one hand, a special discipline - the national philology, and, on the other hand, the discipline that in the light of Polish Higher Education Reforms: Ustawa 2.0 (Law 2.0) is not a discipline. The author tries to problematise the notions of perspective and globality in reference to Polish studies as well as, in this context, to investigate the case of the humanities of protest that he analyses as based on the Hong Kong 2019 manifestations. The author is of the opinion that the waves of demonstrations staged on the Polish streets after completing the present paper gives the study new meanings: closer and more actual. 